Brazilian Journal

of Chemical

ISSN 0104-6632

Printed in Brazil

Engineering

www.scielo.br/bjce

Vol. 35, No. 02, pp. 509 - 520, April - June, 2018

(cc) BY

dx.doi.org/10.1590/0104-6632.20180352s20160545

\title{
CAROTENOID PRODUCTION BY SPORIDIOBOLUS PARAROSEUS IN AGROINDUSTRIAL MEDIUM: OPTIMIZATION OF CULTURE CONDITIONS IN SHAKE FLASKS AND SCALE-UP IN A STIRRED TANK FERMENTER
}

\author{
Carina Molins Borba ${ }^{1 *}$, Millene das Neves Tavares ${ }^{1}$, Caroline Costa \\ Moraes $^{2}$ and Janaína Fernandes de Medeiros Burkert ${ }^{1}$ \\ ${ }^{1}$ Laboratório de Engenharia de Bioprocessos, Universidade Federal do Rio Grande, Avenida \\ Itália, km 08, Campus Carreiros, Escola de Química e Alimentos, Mailbox: 474, Zip code: \\ 96203900 - Rio Grande, RS - Brazil. \\ ${ }^{2}$ Laboratório de Microbiologia e Toxicologia de Alimentos, Universidade Federal do Pampa, \\ Maria Anunciação Gomes de Godoy, n¹650, Malafaia, Zip Code: 96413-170-Bagé, RS- Brazil.
}

(Submitted: September 15, 2016; Revised: March 14, 2017; Accepted: June 4, 2017)

\begin{abstract}
Biotechnological production of carotenoids can be affected by cultivation conditions, such as temperature, $\mathrm{pH}$ and agitation. The aim of this study was to maximize carotenoid production by Sporidiobolus pararoseus in shake flasks with agroindustrial by-products as substrates. The best conditions were used in a stirred tank fermenter. The medium consisted of corn steep liquor and sugar cane molasses pretreated with sulfuric acid. In order to evaluate the effects of the variables, a central composite rotatable design was used. The highest values of total carotenoids $\left(565 \mu \mathrm{g} \mathrm{L}^{-1}\right)$, biomass $\left(13.6 \mathrm{~g} \mathrm{~L}^{-1}\right)$ and $\mathrm{Y}_{\mathrm{p} / \mathrm{s}}\left(10.9 \mu \mathrm{g} \mathrm{g}^{-1}\right)$ were obtained in Assay 13 at $27.5^{\circ} \mathrm{C}$, $150 \mathrm{rpm}$ and $\mathrm{pH}=4$, in Erlenmeyer flasks. For the best conditions defined for carotenoid productivity and $1.2 \mathrm{vvm}$ in the stirred tank fermenter, the maximum value was $1969.3 \mu \mathrm{g} \mathrm{L}^{-1}$ of total carotenoids. It was 3.5-fold higher than the value obtained when shake flasks were used.
\end{abstract}

Keywords: yeast, molasses, experimental design.

\section{INTRODUCTION}

Biotechnology has great importance in various areas, such as pharmaceutical, food, agricultural and environmental (Fossi et al., 2016; Pleszczynska et al., 2016; Riaño et al., 2016; Kavino et al., 2007). The use of yeast has been highlighted in the production of a wide range of compounds, such as lipids (Gong et al., 2016), enzymes (Otero et al., 2015) and carotenoids (Cipolatti et al., 2015; Damodaran et al., 2007).

*Corresponding author. carinamolinsborba@yahoo.com.br
Red yeasts belonging to the genus Sporidiobolus can grow and produce carotenoids (the major one is $\beta$-carotene) efficiently in an alternative medium, such as corn steep liquor combined with sugar cane molasses (Machado and Burkert, 2015; Cipolatti, 2012).

More than 15 million tons of corn were produced in Brazil in 2015 (IBGE, 2016). In order to reduce losses, corn is subjected to humidification during its processing, and the residual water is called corn steep liquor (Liggett and Koffler, 1948). The composition of the water, which is quite variable depending on the corn which is used, may include carbon, hydrogen 
and nitrogen (Cipolatti, 2012). More than 10 million tons of sugar cane were also produced in Brazil in 2015 (IBGE, 2016). The industrial processing of sugar cane results in the by-product known as sugar cane molasses, whose composition has more than $30 \%$ of carbon (Valduga et al., 2007; Cipolatti, 2012).

This ability makes them promising for the industrial bioproduction of carotenoids, not only to minimize costs with the cultivation medium, but also to add value to the agroindustrial waste. Cultivation conditions can interfere in carotenoid production by red yeasts. Temperature is one of the most important environmental factors for the development of organisms, since it entails changes in biosynthetic pathways, including carotenoid biosynthesis (Bhosale, 2004). The $\mathrm{pH}$ level can affect cell growth and product formation. In general, the resulting effects depend on the microorganisms, medium composition and operational conditions (Saenge et al., 2011).

In aerobic microorganisms, aeration plays the major role in the growth rate and carotenoid production, since oxygen transfer becomes a limiting factor when cells grow and the viscosity of the broth increases (Mantzouridou et al., 2002). In shake flasks, oxygen transport is a consequence of the incubator shaking, while in stirred tank fermenters, oxygen is provided by a compressed air line. Stirring blades improve medium mixing and the distribution of air bubbles; reduction in the size of the bubbles increases their surface areas (Garcia-Ochoa et al., 2010).

Data collected by BCC Research (2015) show that the global carotenoid market value was $\$ 1.5$ billion in 2014 and it is expected to reach nearly $\$ 1.8$ billion in 2019. The favorable scenario, along with increasing concerns for the risks of consuming synthetic dyes (Batada and Jacobson, 2016; Dafallah et al., 2015), makes of great interest studies whose objectives are to increase productivity and reduce production costs of natural dyes, such as carotenoids. Therefore, the aim of this study was to maximize carotenoid production by the new strain Sporidiobolus pararoseus in shake flasks with agroindustrial by-products as substrates. The best conditions were used in a stirred tank fermenter.

\section{MATERIALS AND METHODS}

\section{Microorganism}

The new yeast strain Sporidiobolus pararoseus, which was used in this study, had been previously isolated in Caçapava do Sul, a city located in the
Escudo Sul-riograndense ecosystem (Rio Grande do Sul state, Brazil) from environmental samples (Otero, 2011), identified and deposited at the André Tosello Tropical Culture Collection (CCT 7689).

\section{Maintenance and reactivation of the microorganism}

The microorganism was maintained in inclined tubes with YM agar $\left(3.0 \mathrm{~g} \mathrm{~L}^{-1}\right.$ yeast extract, $3.0 \mathrm{~g}$ $\mathrm{L}^{-1}$ malt extract, $5.0 \mathrm{~g} \mathrm{~L}^{-1}$ peptone, $10.0 \mathrm{~g} \mathrm{~L}^{-1}$ glucose and $20 \mathrm{~g} \mathrm{~L}^{-1}$ agar). For reactivation, samples were transferred from stock cultures to other tubes with the same medium and incubated at $25^{\circ} \mathrm{C}$ for $48 \mathrm{~h}$. Cell resuspension (pre-inoculum) was performed in $1.0 \mathrm{~mL}$ peptone water $(0.1 \%)$, added to $9 \mathrm{~mL}$ of previously optimized medium - composed of $40.0 \mathrm{~g} \mathrm{~L}^{-1}$ sugar cane molasses and $6.5 \mathrm{~g} \mathrm{~L}^{-1}$ corn steep liquor, pretreated with sulfuric acid (Machado and Burkert, 2015) - and incubated in the same conditions previously described.

\section{Pretreatment of substrates}

For the pretreatment of the medium, both substrates, molasses and corn steep liquor, were separately acidified to $\mathrm{pH}=3.0$ by the addition of $1 \mathrm{~N}$ sulfuric acid and allowed to rest for $24 \mathrm{~h}$ at room temperature. After this period, they were centrifuged at $3439 \mathrm{xg}$ for $10 \mathrm{~min}$ and the $\mathrm{pH}$ was adjusted in agreement with the experimental design, before the sterilization process, with the addition of a $\mathrm{NaOH}$ or sulfuric acid solution (Machado and Burkert, 2015).

\section{Inoculum preparation}

The pre-inoculum was added to $250 \mathrm{~mL}$ Erlenmeyer flasks with $90 \mathrm{~mL}$ of medium $\left(40.0 \mathrm{~g} \mathrm{~L}^{-1}\right.$ sugar cane molasses and $6.5 \mathrm{~g} \mathrm{~L}^{-1}$ corn steep liquor, pretreated with sulfuric acid) which had been previously sterilized at $121^{\circ} \mathrm{C}$ for $15 \mathrm{~min}$ (Machado and Burkert, 2015). The inoculum was incubated at $25^{\circ} \mathrm{C}$, at $150 \mathrm{rpm}$ for 48 $\mathrm{h}$ or the time necessary to achieve $1 \times 10^{7}$ cells $\mathrm{mL}^{-1}$, counted with a Neubauer chamber (Michelon et al, 2012).

\section{Influence of the volume of the production medium in relation to the volume of the reactor in shake flasks}

In order to evaluate the influence of the volume of the production medium in relation to the volume of the reactor, experiments were carried out in three ratios: $30 \%$ (500 mL Erlenmeyer with $150 \mathrm{~mL}$ medium), $50 \%$ (500 mL Erlenmeyer with $250 \mathrm{~mL}$ medium) and $70 \%$ (500 mL Erlenmeyer with $350 \mathrm{~mL}$ medium). 
Previously optimized culture medium (Machado and Burkert, 2015) - composed of $40.0 \mathrm{~g} \mathrm{~L}^{-1}$ sugar cane molasses and $6.5 \mathrm{~g} \mathrm{~L}^{-1}$ corn steep liquor, pretreated with sulfuric acid at pH 5 (Rios et al., 2015) - and 10\% inoculum were used.

\section{Optimization of the conditions of carotenoid pro- duction in shake flasks with agroindustrial medium}

For the carotenoid bioproduction, $500 \mathrm{~mL}$ Erlenmeyer flasks with $225 \mathrm{~mL}$ culture medium (40.0 $\mathrm{g} \mathrm{L}^{-1}$ sugar cane molasses and $6.5 \mathrm{~g} \mathrm{~L}^{-1}$ corn steep liquor, pretreated with sulfuric acid) and $25 \mathrm{~mL}(10 \%)$ inoculum were used. To evaluate the effects of the variables temperature $\left(20-35^{\circ} \mathrm{C}\right)$, agitation $(100-200$ rpm) and initial $\mathrm{pH}$ (4-8) on carotenoid production by $S$. pararoseus, an experimental design was used (Table 1), with pretreated substrates. Samples were taken every $24 \mathrm{~h}$ to monitor biomass concentration, $\mathrm{pH}$, total reducing sugars and total carotenoids. Total cultivation time was $240 \mathrm{~h}$.

\section{Culture in stirred tank fermenters}

Production was carried out with the stirred tank fermenter Biostat $2 \mathrm{~L}$ (1.5 L working volume), using medium with $40.0 \mathrm{~g} \mathrm{~L}^{-1}$ sugar cane molasses and 6.5 $\mathrm{g} \mathrm{L}^{-1}$ corn steep liquor pretreated with sulfuric acid, temperature control at $25^{\circ} \mathrm{C}$, initial $\mathrm{pH}=6.0$, at 158 rpm and $1.2 \mathrm{vvm}$ (Hui et al., 2007) for $168 \mathrm{~h}$. Biomass, $\mathrm{pH}$, total reducing sugars and total carotenoids were monitored in this period.

\section{Extraction and determination of total carotenoids}

Recovery of total carotenoids began with biomass centrifugation at $3439 \mathrm{xg}$ for $10 \mathrm{~min}$. It was then transferred to a Petri dish, placed in a circulating air oven $\left(35^{\circ} \mathrm{C}\right.$ for $48 \mathrm{~h}$ ) (Fonseca et al., 2011), macerated to a standardized degree by a 115 mesh sieve and frozen at $-18^{\circ} \mathrm{C}$ for $48 \mathrm{~h}$ (Cipolatti et al., 2015). Once frozen, the biomass was lysed with the rupture agent dimethyl sufoxide (DMSO), followed by vortexing for $1 \mathrm{~min}$ at 15 min intervals for $1 \mathrm{~h}$ (Fonseca et al., 2011). After rupture, acetone was added, followed by centrifugation (3439 xg for $10 \mathrm{~min}$ ). The supernatant was separated and successive extractions were performed until total bleaching of the cell.

To the solvent phases obtained by centrifugation, $20 \% \mathrm{NaCl}$ solution $\left(\mathrm{w} \mathrm{v}^{-1}\right)$ and petroleum ether were added. After the formation of both phases, the polar phase was collected and excess water was removed by sodium sulfate (Michelon et al., 2012), thus, forming the carotenogenic extracts.

Concentrations of specific carotenoids in the extracts were determined by a spectrophotometer (Biospectro SP-220, China). Maximum absorbance average was $448 \mathrm{~nm}$, expressed in terms of its major carotenoid ( $\beta$-carotene), using Equation 1 (Davies, 1976):

$$
T C=\frac{A^{*} V^{*} 10^{6}}{A_{1 c m}^{1 \% *} 100^{*} m_{\text {sample }}}
$$

where TC is the total carotenoid concentration $\left(\mu \mathrm{g} \mathrm{g}^{-1}\right)$, A is the absorbance, $\mathrm{V}$ is the volume $(\mathrm{mL}), \mathrm{m}_{\text {sample }}$ is the

Table 1. Coded values and real values (in parentheses) for the central composite rotational design (CCRD) and the response variables.

\begin{tabular}{|c|c|c|c|c|c|c|c|c|c|c|c|}
\hline Assay & $\mathrm{X}_{1}$ & $\mathrm{X}_{2}$ & $\mathrm{X}_{3}$ & $\mathrm{R}_{1}^{*}$ & $\mathrm{R}_{2}^{*}$ & $\mathrm{R}_{3}$ & $\mathrm{R}_{4}$ & $\mathrm{R}_{5}$ & $\mathrm{R}_{6}$ & $\mathrm{R}_{7}$ & $\mathrm{R}_{8}$ \\
\hline 1 & $-1.00(23)$ & $-1.00(120)$ & $-1.00(5.2)$ & $324(192$ h) & $11.1(240 \mathrm{~h})$ & 0.036 & 6.5 & 0.20 & 28.3 & 0.04 & 1.5 \\
\hline 2 & $1.00(32)$ & $-1.00(120)$ & $-1.00(5.2)$ & $164(216 \mathrm{~h})$ & $3.6(216 \mathrm{~h})$ & 0.002 & 2.9 & 0.07 & 42.9 & 0.01 & 0.5 \\
\hline 3 & $-1.00(23)$ & $1.00(180)$ & $-1.00(5.2)$ & $412(168 \mathrm{~h})$ & $12.5(192 \mathrm{~h})$ & 0.039 & 7.8 & 0.22 & 33.6 & 0.06 & 2.3 \\
\hline 4 & $1.00(32)$ & $1.00(180)$ & $-1.00(5.2)$ & $172(240 \mathrm{~h})$ & $7.7(240$ h) & 0.009 & 3.0 & 0.14 & 17.0 & 0.03 & 0.5 \\
\hline 5 & $-1.00(23)$ & $-1.00(120)$ & $1.00(7.2)$ & $185(120 \mathrm{~h})$ & $5.8(240 \mathrm{~h})$ & 0.030 & 5.2 & 0.11 & 28.5 & 0.02 & 1.2 \\
\hline 6 & $1.00(32)$ & $-1.00(120)$ & $1.00(7.2)$ & $89(240$ h) & $2.6(240 \mathrm{~h})$ & 0.024 & 1.6 & 0.04 & 40.8 & 0.01 & 0.3 \\
\hline 7 & $-1.00(23)$ & $1.00(180)$ & $1.00(7.2)$ & 396 (144 h) & $9.7(216 \mathrm{~h})$ & 0.039 & 7.2 & 0.23 & 28.7 & 0.04 & 1.7 \\
\hline 8 & $1.00(32)$ & $1.00(180)$ & $1.00(7.2)$ & $222(216 \mathrm{~h})$ & $5.3(240 \mathrm{~h})$ & 0.010 & 4.6 & 0.10 & 44.7 & 0.02 & 0.9 \\
\hline 9 & $-1.68(20)$ & $0(150)$ & $0(6)$ & $287(168 \mathrm{~h})$ & $10.7(216 \mathrm{~h})$ & 0.039 & 4.9 & 0.27 & 17.0 & 0.04 & 1.0 \\
\hline 10 & $1.68(35)$ & $0(150)$ & $0(6)$ & $137(24 \mathrm{~h})$ & $3.4(24 \mathrm{~h})$ & 0.001 & 0.0 & 0.44 & 0.0 & 0.10 & 0.0 \\
\hline 11 & $0(27.5)$ & $-1.68(100)$ & $0(6)$ & $133(48 \mathrm{~h})$ & $3.2(48 \mathrm{~h})$ & 0,025 & 1.5 & 0.07 & 22.3 & 0.05 & 1.1 \\
\hline 12 & $0(27.5)$ & $1.68(200)$ & $0(6)$ & $232(192 \mathrm{~h})$ & $6.6(216 \mathrm{~h})$ & 0.025 & 4.6 & 0.19 & 22.9 & 0.03 & 0.7 \\
\hline 13 & $0(27.5)$ & $0(150)$ & $-1.68(4)$ & $565(240 \mathrm{~h})$ & $13.6(192 \mathrm{~h})$ & 0.025 & 10.9 & 0.26 & 43.0 & 0.07 & 2.3 \\
\hline 14 & $0(27.5)$ & $0(150)$ & $1.68(8)$ & 203 (144 h) & $4.1(240 \mathrm{~h})$ & 0.025 & 6.1 & 0.07 & 57.7 & 0.01 & 1.3 \\
\hline 15 & $0(27.5)$ & $0(150)$ & $0(6)$ & $503(168 \mathrm{~h})$ & $6.7(168 \mathrm{~h})$ & 0.030 & 9.5 & 0.11 & 83.7 & 0.03 & 2.9 \\
\hline 16 & $0(27.5)$ & $0(150)$ & $0(6)$ & $520(168 \mathrm{~h})$ & $6.6(216 \mathrm{~h})$ & 0.030 & 10.2 & 0.12 & 87.9 & 0.03 & 3.0 \\
\hline
\end{tabular}

$\mathrm{X}_{1}$ : Temperature $\left({ }^{\circ} \mathrm{C}\right) ; \mathrm{X}_{2}$ : Agitation (rpm); $\mathrm{X}_{3}$ : initial $\mathrm{pH} ; \mathrm{R}_{1}$ : Total Carotenoids $\left(\mu \mathrm{g} \mathrm{L}{ }^{-1}\right) ; \mathrm{R}_{2}:$ Biomass $\left(\mathrm{g} \mathrm{L}^{-1}\right) ; \mathrm{R}_{3}: \mu_{\max }\left(\mathrm{h}^{-1}\right) ; \mathrm{R}_{4}: \mathrm{Y}_{\mathrm{p} / \mathrm{s}}\left(\mu \mathrm{g} \mathrm{g}^{-1}\right) ; \mathrm{R}_{5}: \mathrm{Y}_{\mathrm{x} / \mathrm{s}}$ $\left(\mathrm{g} \mathrm{g}^{-1}\right) ; \mathrm{R}_{6}: \mathrm{Y}_{\mathrm{p} / \mathrm{x}}\left(\mu \mathrm{g} \mathrm{g}^{-1}\right) ; \mathrm{R}_{7}: \mathrm{P}_{\mathrm{x}}\left(\mathrm{g} \mathrm{L}^{-1} \mathrm{~h}^{-1}\right) ; \mathrm{R}_{8}: \mathrm{P}_{\mathrm{c}}\left(\mu \mathrm{g} \mathrm{L}^{-1} \mathrm{~h}^{-1}\right) ;{ }^{*}$ In parentheses is the time at which this variable was at the maximum value. 
dry cell mass $(\mathrm{g})$ and $A_{1 c m}^{1 \%}$ is the specific absorptivity $(\beta$-carotene in petroleum ether $=2592)$. To calculate total carotenoids $\left(\mu \mathrm{g} \mathrm{L}^{-1}\right)$ with the results of the specific concentration and biomass concentration, unit conversion was performed.

\section{Determination of $\mathrm{pH}$}

Culture $\mathrm{pH}$ was determined by a pHmeter (Marte, MB-10, Brazil), in agreement with AOAC (2000).

\section{Biomass concentration}

Cell concentration was estimated throughout the process of carotenoid bioproduction by reading the absorbance at $620 \mathrm{~nm}$ with a previously constructed standard curve (Choi and Park, 2003).

\section{Determination of total reducing sugars}

Total reducing sugar (TRS) concentrations were determined in cell-free supernatant. Two $\mathrm{mL}$ of culture medium were submitted to hydrolysis with $2 \mathrm{~mL} \mathrm{HCl}$ $2.0 \mathrm{~mol} \mathrm{~L}^{-1}$ in boiling water for $10 \mathrm{~min}$, followed by the addition of $2 \mathrm{~mL}$ of $\mathrm{NaOH} 2.0 \mathrm{~mol} \mathrm{~L}^{-1}$ for acid neutralization (Maldonade et al., 2013). Subsequently, total reducing sugars were determined by the spectrophotometric method of 3,5-dinitrosalicylic acid (DNS), according to Miller (1959), with a standard glucose curve.

\section{Kinetic parameters}

For kinetic parameters, data were obtained by analytical methodologies and calculated according to Hiss (2001). Maximum specific growth rate $-\mu_{\max }\left(\mathrm{h}^{-1}\right)$ was calculated with the help of the Software Grapher 8 by linear regression of the exponential phase, using Equation 2:

$$
\mu_{\max }=\frac{1}{X} \frac{d X}{d t}
$$

TRS in product conversion factors $\left(\mathrm{Y}_{\mathrm{p} / \mathrm{s}}\left(\mu \mathrm{g} \mathrm{g}^{-1}\right)\right)$, TRS in biomass $\left(\mathrm{Y}_{\mathrm{x} / \mathrm{s}}\left(\mathrm{g} \mathrm{g}^{-1}\right)\right)$ and biomass in product

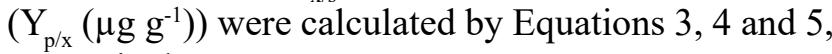
respectively:

$$
\begin{gathered}
Y_{p / s}=\frac{P_{m}-P_{0}}{S_{0}-S} \\
Y_{\mathrm{x} / \mathrm{s}}=\frac{X_{m}-X_{0}}{S_{0}-S} \\
Y_{p / x}=\frac{P_{m}-P_{0}}{X_{m}-X_{0}}
\end{gathered}
$$

where $\mathrm{X}_{\mathrm{m}}$ is the maximum biomass concentration $(\mathrm{g}$ $\left.\mathrm{L}^{-1}\right), \mathrm{X}_{0}$ is the initial biomass concentration $\left(\mathrm{g} \mathrm{L}^{-1}\right), \mathrm{P}_{\mathrm{m}}$ is the maximum carotenoid concentration $\left(\mu \mathrm{g} \mathrm{L}^{-1}\right), \mathrm{P}_{0}$ is the initial carotenoid concentration $\left(\mu \mathrm{g} \mathrm{L}^{-1}\right), \mathrm{S}_{0}$ is the initial TRS concentration $\left(\mathrm{g} \mathrm{L}^{-1}\right)$ and $\mathrm{S}$ is the final TRS concentration $\left(\mathrm{g} \mathrm{L}^{-1}\right)$.

In order to evaluate the performance of the fermentation process, productivities of carotenoid - $\mathrm{P}$ $\left(\mu \mathrm{g} \mathrm{L}^{-1} \mathrm{~h}^{-1}\right)$ and biomass - $\mathrm{P}_{\mathrm{x}}\left(\mathrm{g} \mathrm{L}^{-1} \mathrm{~h}^{-1}\right)$ were calculated from Equations 6 and 7, respectively:

$$
\begin{aligned}
& P_{c}=\frac{P_{m}-P_{0}}{t_{f}} \\
& P_{\mathrm{x}}=\frac{X_{m}-X_{0}}{t_{f}}
\end{aligned}
$$

where $\mathrm{X}_{\mathrm{m}}$ is the maximum biomass concentration ( $\mathrm{g}$ $\left.\mathrm{L}^{-1}\right), \mathrm{X}_{0}$ is the initial biomass concentration $\left(\mathrm{g} \mathrm{L}^{-1}\right), \mathrm{P}_{\mathrm{m}}$ is the maximum carotenoid concentration $\left(\mu \mathrm{g} \mathrm{L}^{-1}\right), \mathrm{P}_{0}$ is the initial carotenoid concentration $\left(\mu \mathrm{g} \mathrm{L}^{-1}\right)$ and $\mathrm{t}_{\mathrm{f}}$ is the fermentation time in which maximum biomass or product (h) was obtained.

\section{Statistical analysis}

Data were treated with the aid of Statistica 5.0 (StartSoft Inc., Tulsa, OK, USA). All analyses considered $90 \%$ confidence level $(p<0.1)$. The analysis of variance (ANOVA) was used for estimating statistical parameters. Response surfaces were drawn in agreement with Box et al. (1978).

\section{RESULTS AND DISCUSSION}

Nitrogen, carbon, temperature, agitation and $\mathrm{pH}$ are some of the factors that can affect carotenoid production separately or synergistically (Aksu and Eren, 2007; Rios et al., 2015). In this study, temperature, $\mathrm{pH}$ and agitation were investigated in the search for the best conditions for carotenoid production by Sporidiobolus pararoseus.

\section{Influence of the volume of the production medium in relation to the volume of the reactor}

Figure 1 shows the results of total carotenoids obtained for the ratios medium volume: reactor volume of 30,50 and $70 \%$. The volume variation of the medium in the reactor can affect oxygen transfer. Liu et al., (2006) characterized the transfer of oxygen during the cultivation of Phafiia rhodozyma and, based on linear regression of experimental data, observed that the oxygen transfer coefficient was correlated 


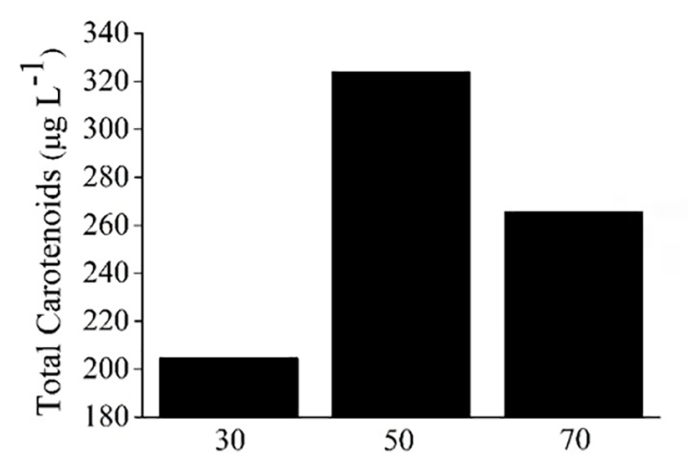

Relation volume reactor:volume medium (\%)

Figure 1. Carotenoid production at different ratios of medium volume: reactor volume

with shaker speed and liquid volume. In the same study, the authors report that the carotenoid yield showed a strong linear correlation with the oxygen transfer rate demonstrating that oxygen supply is crucial for carotenoid production in liquid cultures. The effect of oxygen transfer on the production of biomass and carotenoids was also demonstrated by other authors using Rhodotorula rubra (Cutzu et al., 2013) and Blakeslea trispora (Mantzouridou et al., 2005). Therefore, it is of great importance to define a ratio of medium volume: reactor volume that allows an adequate transfer of oxygen, since this parameter is directly dependent on the liquid side mass transfer coefficient, the total specific surface area available for mass transfer and the driving force in terms of concentrations (Garcia-Ochoa et al., 2010). In the present study the highest concentration of carotenoids was obtained with the $50 \%$ ratio, which was chosen for further work.

\section{Optimization of the conditions of carotenoid production in shake flasks with agroindustrial medium}

Table 1 shows the central composite rotatable design (CCRD) $2^{3}$. Times in which the highest carotenoid and biomass concentrations were obtained are indicated between parentheses. It is worth mentioning that the smallest values of responses under study were obtained in conditions in which temperatures were maintained above $30^{\circ} \mathrm{C}$ (Assays 2, 4, 6, 8 and 10). Low productions observed at high temperatures may have been the result of changes in the major carotenoid. According to Frengova and Beshkova (2009), the effect of temperature depends on the microorganism species; it often manifests itself in a number of variations in synthesized carotenoids. El-Banna et al. (2012) showed that temperature range from 15 to $35^{\circ} \mathrm{C}$ in the cultivation of Rhodotorula glutinis led to changes in the percentage of produced $\beta$-carotene and torulene. When the temperature was raised to $30^{\circ} \mathrm{C}, \beta$-carotene was the major carotenoid produced by the yeast, representing up to $60 \%$ of the production. However, when the temperature reached $35^{\circ} \mathrm{C}$, this ratio was reversed and torulene represented $61 \%$ of total carotenoid production.

The highest values of total carotenoids (565 $\left.\mu \mathrm{g} \mathrm{L}^{-1}\right)$, biomass $\left(13.6 \mathrm{~g} \mathrm{~L}^{-1}\right)$ and substrate to product conversion factor $\left(\mathrm{Y}_{\mathrm{p} / \mathrm{s}}=10.9 \mu \mathrm{g} \mathrm{g}^{-1}\right)$ were obtained in Assay 13 , at $27.5^{\circ} \mathrm{C}$, at $150 \mathrm{rpm}$ (central points) and $\mathrm{pH}=4$ (-1.68).

Valduga et al. (2008) found similar results to those obtained in this study regarding the increased production of carotenoids in acid $\mathrm{pH}$ with $S$. salmonicolor and medium composed of $10 \mathrm{~g} \mathrm{~L}^{-1}$ molasses, $5 \mathrm{~g} \mathrm{~L}^{-1}$ corn steep liquor and $5 \mathrm{~g} \mathrm{~L}^{-1}$ Prodex Lac $\AA$, pre-treated with sulfuric acid, at $25^{\circ} \mathrm{C}$, at $180 \mathrm{rpm}$, initial $\mathrm{pH}$ 4.0. Their production reached $541.5 \mu \mathrm{g} \mathrm{L}^{-1}$.

TRS consumption (analyzed as glucose) during cultivation (data not shown) ranged from $68 \%$ (Assay 10) to $96 \%$ (Assay 3). Assays with the highest TRS consumption occurred at $180 \mathrm{rpm}$ (Assays 3, 4 and 8) and at $150 \mathrm{rpm}$ (Assays 13, 14, 15, 16 and 17). The lowest TRS consumption (Assays 11, 6 and 2) occurred at the lowest agitation (100-120 rpm) and caused the three lowest $Y_{p / s}\left(1.54 ; 1.56 ; 2.86 \mu \mathrm{g} \mathrm{g}^{-1}\right)$ and $Y_{x / s}(0.07$; $\left.0.04 ; 0.07 \mathrm{gg}^{-1}\right)$ values. In Assay 10, despite the fact that agitation was $150 \mathrm{rpm}, \mathrm{Y}_{\mathrm{p} / \mathrm{s}}$ was close to zero, probably because the temperature was $35^{\circ} \mathrm{C}$ (level +1.68$)$. The effect of agitation on cell development was previously observed in Rhodotorula glutinis cultivation, from 100 to $150 \mathrm{rpm}$, when the yeast showed less cell growth, probably due to the decrease in nutrients available on the cell surface, whereas high stirring rates (more than $250 \mathrm{rpm}$ ) caused cell disruption (Tinoi et al., 2005).

The use of an experimental design enables the study of the influence of the levels of one variable on the responses. Table 2 shows regression coefficients, standard deviations and $\mathrm{p}$ and $\mathrm{t}$ values used in the construction of the models (Equations 8, 9 and 10).

On the basis of the analysis of variance (ANOVA), as shown in Table 3, second-order Equations 8, 9 and 10 were established to describe the total carotenoid concentration, biomass concentration and carotenoid productivity $\left(\mathrm{P}_{c}\right)$, respectively, as a function of temperature, agitation and $\mathrm{pH}$. The pure error was very low, indicating good reproducibility of the experimental data. Based on the F test, the models are predictive, since the calculated $F$ values are higher than the critical $F$ values $(3.6,10$ and 6.4-fold for carotenoid and biomass concentrations 
Table 2. Regression coefficients (RC), standard errors (SE) and t from the central composite rotational design (CCRD) for the responses total carotenoids, biomass concentration and $\mathrm{P}_{\mathrm{c}}$.

\begin{tabular}{|c|c|c|c|c|c|c|c|c|c|c|c|}
\hline & \multicolumn{3}{|c|}{ Total Carotenoids $\left(\mu \mathrm{g} \mathrm{L}^{-1}\right)$} & \multicolumn{5}{|c|}{ Biomass $\left(\mathrm{g} \mathrm{L}^{-1}\right)$} & \multicolumn{3}{|c|}{$P_{c}\left(\mu g L^{-1} h^{-1}\right)$} \\
\hline & RC & SE & $t(6)$ & & RC & SE & $t(6)$ & & RC & SE & $t(6)$ \\
\hline Mean & $511.16^{*}$ & 50.80 & 10.06 & Mean & $6.61 *$ & 0.90 & 7.34 & Mean & $2.945 *$ & 0.29 & 10.04 \\
\hline$X_{1}(L)$ & $-67.53 *$ & 39.02 & -3.46 & $\mathrm{X}_{1}(\mathrm{~L})$ & $2.36^{*}$ & 0.69 & -6.81 & $\mathbf{X}_{1}(\mathrm{~L})$ & $-0.447^{*}$ & 0.22 & -3.97 \\
\hline $\mathbf{X}_{1}(\mathbf{Q})$ & $-105.59 *$ & 47.42 & -4.45 & $\mathbf{X}_{1}(\mathbf{Q})$ & 0.22 & 0.84 & 0.52 & $\mathbf{X}_{1}(\mathbf{Q})$ & $-0.834^{*}$ & 0.27 & -6.09 \\
\hline $\mathbf{X}_{2}(\mathrm{~L})$ & $44.51 *$ & 39.02 & 2.28 & $\mathrm{X}_{2}(\mathrm{~L})$ & $1.30^{*}$ & 0.69 & 3.77 & $\mathrm{X}_{2}(\mathrm{~L})$ & 0.09 & 0.22 & 0.84 \\
\hline $\mathbf{X}_{2}(\mathbf{Q})$ & $-116.09 *$ & 47.42 & -4.90 & $\mathbf{X}_{2}(\mathbf{Q})$ & -0.54 & 0.84 & -1.29 & $X_{2}(Q)$ & $-0.07^{*}$ & 0.27 & -5.11 \\
\hline $\mathbf{X}_{3}(\mathrm{~L})$ & $-57.80 *$ & 39.02 & -2.96 & $\mathrm{X}_{3}(\mathrm{~L})$ & $2.01 *$ & 0.69 & -5.81 & $\mathrm{X}_{3}(\mathrm{~L})$ & -0.170 & 0.22 & -1.51 \\
\hline $\mathbf{X}_{3}(\mathbf{Q})$ & -44.63 & 47.42 & -1.88 & $\mathbf{X}_{3}(\mathbf{Q})$ & $0.85^{*}$ & 0.84 & 2.04 & $\mathbf{X}_{3}(\mathbf{Q})$ & $-0.377^{*}$ & 0.27 & -2.75 \\
\hline $\mathbf{X}_{1} \mathbf{X}_{2}$ & -19.92 & 50.96 & -0.78 & $\mathbf{X}_{1} \mathbf{X}_{2}$ & 0.19 & 0.90 & 0.41 & $\mathbf{X}_{1} \mathbf{X}_{2}$ & -0.099 & 0.29 & -0.67 \\
\hline $\mathbf{X}_{1} \mathbf{X}_{3}$ & 16.32 & 50.96 & 0.64 & $\mathbf{X}_{1} \mathbf{X}_{3}$ & 0.59 & 0.90 & 1.30 & $\mathbf{X}_{1} \mathbf{X}_{3}$ & 0.132 & 0.29 & 0.90 \\
\hline $\mathbf{X}_{2} \mathbf{X}_{3}$ & 30.90 & 50.96 & 0.21 & $\mathbf{X}_{2} \mathbf{X}_{3}$ & 0.14 & 0.90 & 0.30 & $\mathbf{X}_{2} \mathbf{X}_{3}$ & 0.052 & 0.29 & 0.35 \\
\hline
\end{tabular}

$*(\mathrm{p}<0.1) ; \mathrm{X}_{1}$ : temperature; $\mathrm{X}_{2}$ : agitation; $\mathrm{X}_{3}: \mathrm{pH}$.

Table 3. ANOVA for the CCRD responses total carotenoids, biomass concentration and productivity in carotenoids.

\begin{tabular}{|c|c|c|c|c|c|}
\hline \multicolumn{6}{|c|}{ Total carotenoids } \\
\hline Source of variation & QS & DF & $\mathbf{Q M}$ & $\mathbf{F}_{\text {cal }}$ & $\mathbf{R}^{2}$ \\
\hline Regression & 282612.9 & 5 & 56522.6 & 9 & 0.82 \\
\hline Residue & 62522.2 & 10 & 6252.2 & & \\
\hline Total & 345135.1 & 15 & & & \\
\hline \multicolumn{6}{|c|}{ Biomass } \\
\hline Source of variation & SQ & GL & MQ & $\mathbf{F}_{\text {cal }}$ & $\mathbf{R}^{2}$ \\
\hline Regression & 165.5 & 4 & 41.4 & 25.3 & 0.90 \\
\hline Residue & 17.97 & 11 & 1.6 & & \\
\hline Total & 183.5 & 15 & & & \\
\hline \multicolumn{6}{|c|}{ Productivity in carotenoids } \\
\hline Source of variation & QS & DF & $\mathbf{Q M}$ & $\mathbf{F}_{\text {cal }}$ & $\mathbf{R}^{2}$ \\
\hline Regression & 10.6 & 4 & 1.6 & 16.2 & 0.85 \\
\hline Residue & 1.8 & 11 & 0.2 & & \\
\hline Total & 12.4 & 15 & & & \\
\hline
\end{tabular}

QS: Quadratic Sum; DF: Degrees of freedom; QM: quadratic mean. Total carotenoids: $\mathrm{F}_{\mathrm{tab}}=2.52$; Biomass and productivity in carotenoids: $\mathrm{F}_{\text {tab }}=2.54$.

and $\mathrm{P}_{\mathrm{c}}$, respectively). Regression coefficients $(0.82$, 0.90 and 0.85 ) for total carotenoids, biomass and $P_{c}$, respectively, are considered satisfactory. Parameters that were not significant $(\mathrm{p}>0.1)$ were added to lack of fit in the analysis of variance. Coded models were used to generate response surfaces (Figure 2).

$$
\begin{aligned}
& \text { TC }\left(\mu \mathbf{g ~ L}^{-1}\right)=441.1-67.5 \mathrm{X}_{1}-86.8 \\
& \mathrm{X}_{1}^{2}+44.5 \mathrm{X}_{2}-97.3 \mathrm{X}_{2}^{2}-57.8 \mathrm{X}_{3} \\
& \text { Biomass }\left(\mathrm{g} \mathrm{L}^{-1}\right)=6.3-2.3 \mathrm{X}_{1}+ \\
& 1.30 \mathrm{X}_{2}-2.0 \mathrm{X}_{3}+0.9 \mathrm{X}_{3}^{2} \\
& \mathbf{P}_{\mathbf{c}}\left(\mu \mathbf{g ~ L}^{-1} \mathbf{h}^{-1}\right)=2.9-0.4 \mathrm{X}_{1}-0.8 \\
& \mathrm{X}_{1}^{2}-0.7 \mathrm{X}_{2}^{2}-0.4 \mathrm{X}_{3}^{2}
\end{aligned}
$$

where TC is the total carotenoids, $\mathrm{P}_{\mathrm{c}}$ is the carotenoid productivity, $\mathrm{X}_{1}$ is the temperature, $\mathrm{X}_{2}$ is the agitation and $\mathrm{X}_{3}$ is the $\mathrm{pH}$.
Figures $2 \mathrm{a}, 2 \mathrm{~b}$ and $2 \mathrm{c}$ show that the maximum carotenoid production was optimized. Therefore, agitation should be maintained between 144 and 170 rpm, along with temperatures between 24 and $27.5^{\circ} \mathrm{C}$ and $\mathrm{pH}$ between 4 and 4.2. In order to reach maximal production of biomass (Figure 2c, 2d and 2e), agitation should be maintained between 192 and $200 \mathrm{rpm}$, temperatures between 20 to $21^{\circ} \mathrm{C}$ and initial $\mathrm{pH}$ from 4 to 4.3. Carotenoid productivity (Figure $2 \mathrm{~g}, 2 \mathrm{~h}$ and $2 \mathrm{i}$ ) was also optimized; agitation had to be kept between 132 and $168 \mathrm{rpm}$, temperatures from 25 to $27.5^{\circ} \mathrm{C}$ and $\mathrm{pH}$ from 5.4 to 6.6 .

To find the highest content of carotenoids, models given by Equations 8, 9 and 10 were validated at $27.5^{\circ} \mathrm{C}$, at $150 \mathrm{rpm}$ and initial $\mathrm{pH}=4.0$ (Figure 3a). In this assay, $591.4 \mu \mathrm{g} \mathrm{L}^{-1}$ was obtained in $240 \mathrm{~h}$, approximately $9 \%$ more than the model had predicted (538.2 $\left.\mu \mathrm{g} \mathrm{L}^{-1}\right)$. In the same conditions, $12.8 \mathrm{~g} \mathrm{~L}^{-1}$ 

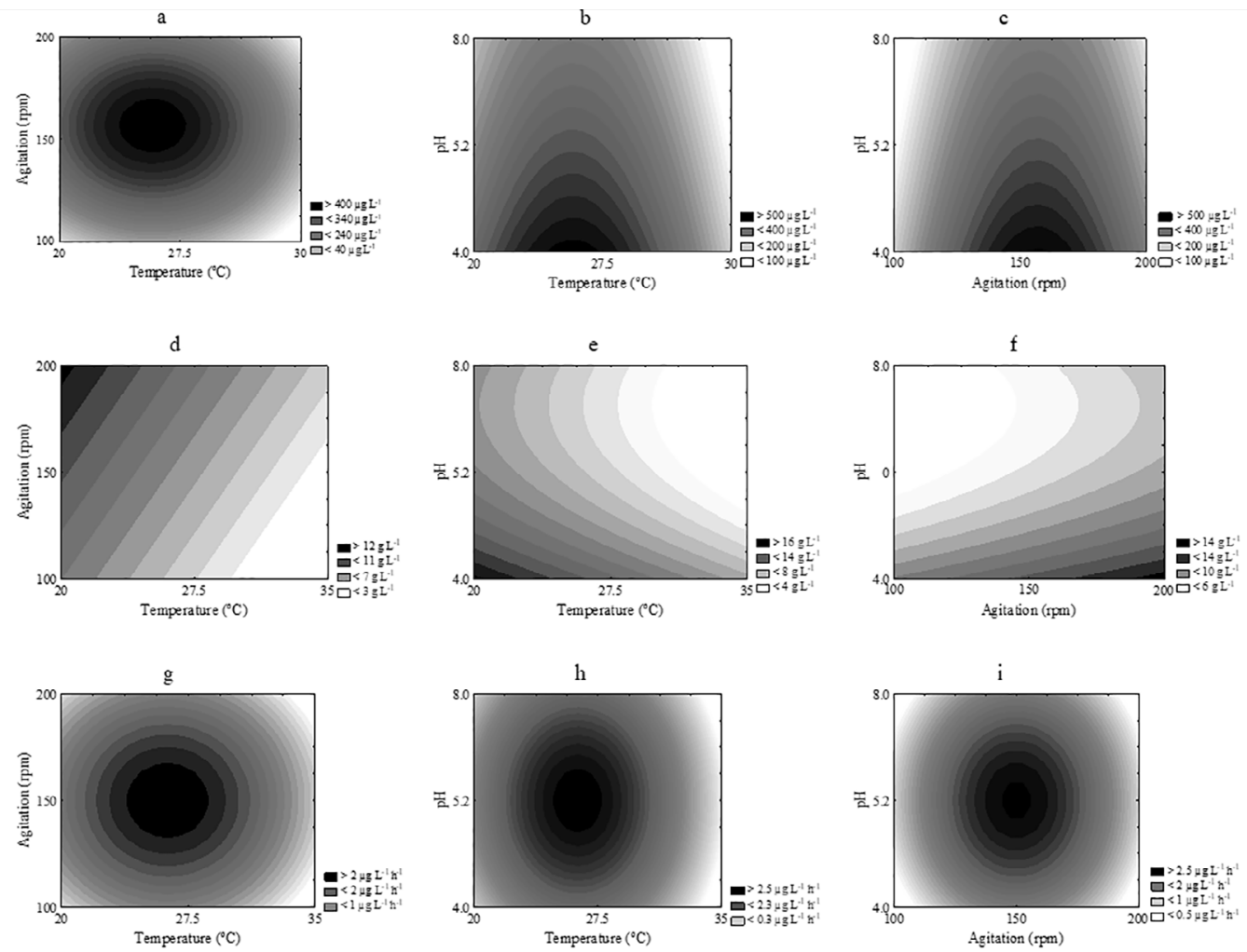

Figure 2. Contour curves of total carotenoids $(a, b, c)$, biomass $(d, e, f)$ and $P_{c}(g, h, i)$.

biomass was obtained, approximately $5 \%$ more than the model had predicted $\left(12.2 \mathrm{~g} \mathrm{~L}^{-1}\right)$, represented by Equation 9. Carotenoid productivity was 2.25 $\mu \mathrm{g} \mathrm{L^{-1 }} \mathrm{h}^{-1}, 27 \%$ more than predicted by Equation 10 $\left(1.77 \mu \mathrm{g} \mathrm{L}^{-1} \mathrm{~h}^{-1}\right)$. The $\mathrm{pH}$ rises until $72 \mathrm{~h}$, whereas no changes were observed afterwards.

Models generated for the other responses were not predictive, so the effects of the variables were of no avail (Figure 4). The use of an experimental design enables the study of the influence of the levels of one variable on the response variable. Thus, the main effects of such a design may be simply calculated as the difference between the average of measurements made at the high level $(+1)$ of the variable and the average of measurements at the low level (-1) (Rodrigues and Iemma, 2012). The variables temperature, agitation and $\mathrm{pH}$, in the ranges under study, did not show significant effects $(p>0.1)$ on the responses $\mathrm{Y}_{\mathrm{x} / \mathrm{s}}$ and $\mathrm{Y}_{\mathrm{p} / \mathrm{x}}$. But the change in the temperature level from -1 to +1 had negative effects on the values of $\mu_{\text {máx }}(-0.025$ $\left.\mathrm{h}^{-1}\right), \mathrm{Y}_{\mathrm{x} / \mathrm{s}}\left(-0.10 \mathrm{~g} \mathrm{~g}^{-1}\right)$ and $\mathrm{P}_{\mathrm{x}}\left(-0.02 \mathrm{~g} \mathrm{~L}^{-1} \mathrm{~h}^{-1}\right)$. Concerning agitation, the effects were positive for $\mathrm{Y}_{\mathrm{x} / \mathrm{s}}\left(0.07 \mathrm{~g} \mathrm{~g}^{-1}\right)$ and $\mathrm{P}_{\mathrm{x}}\left(0.02 \mathrm{~g} \mathrm{~L}^{-1} \mathrm{~h}^{-1}\right)$. Regarding $\mathrm{pH}$, the effect was negative for $\mathrm{P}_{\mathrm{x}}\left(-0.01 \mathrm{~g} \mathrm{~L}^{-1} \mathrm{~h}^{-1}\right)$.

In the conditions of validation in shake flasks $\left(27.5^{\circ} \mathrm{C}, 150 \mathrm{rpm}\right.$ and initial $\left.\mathrm{pH}=4.0\right) 591.4 \mu \mathrm{g} \mathrm{L}^{-1}$ total carotenoids was obtained in $240 \mathrm{~h}$. Biomass was $12.8 \mathrm{~g} \mathrm{~L}^{-1}$ whereas carotenoid productivity was $2.25 \mu \mathrm{g} \mathrm{L}^{-1} \mathrm{~h}^{-1}$. Finally, $\mu_{\max }$ was $0.042 \mathrm{~h}^{-1}, \mathrm{Y}_{\mathrm{p} / \mathrm{s}}$ was $18.35 \mu \mathrm{g} \mathrm{L}^{-1}, \mathrm{Y}_{\mathrm{x} / \mathrm{s}}$ was $0.40 \mathrm{~g} \mathrm{~g}^{-1}, \mathrm{Y}_{\mathrm{p} / \mathrm{x}}$ was $45.33 \mu \mathrm{g} \mathrm{g}^{-1}$ and biomass productivity was $0.05 \mathrm{~g} \mathrm{~L}^{-1} \mathrm{~h}^{-1}$.

\section{Carotenoid production in a stirred tank fermenter}

The principal aim of fermentation scale-up is to produce large quantities of product with high yields in the minimum time possible (Ju and Chase, 1992).

In the stirred tank fermenter, the conditions were the ranges considered to be the best in the experimental design previously introduced for carotenoid productivity: $25^{\circ} \mathrm{C}$, initial $\mathrm{pH} 6.0,158 \mathrm{rpm}$. Aeration was maintained at $1.2 \mathrm{vvm}$ (Hui et al., 2007) for $168 \mathrm{~h}$.

In these conditions (Figure $3 \mathrm{~b}$ ), the maximum values were $1969.3 \mu \mathrm{g} \mathrm{\textrm {L } ^ { - 1 }}$ for total carotenoids, $18.05 \mathrm{~g} \mathrm{~L}^{-1}$ for biomass, $0.044 \mathrm{~h}^{-1}$ for $\mu_{\text {máx }} 37.08 \mu \mathrm{g}$ $\mathrm{L}^{-1}$ for $\mathrm{Y}_{\mathrm{p} / \mathrm{s}}, 0.33 \mathrm{~g} \mathrm{~g}^{-1}$ for $\mathrm{Y}_{\mathrm{x} / \mathrm{s}}, 112.48 \mu \mathrm{g} \mathrm{g}^{-1}$ for $\mathrm{Y}_{\mathrm{p} / \mathrm{x}}$, $0.10 \mathrm{~g} \mathrm{~L}^{-1} \mathrm{~h}^{-1}$ for biomass productivity and $11.48 \mu \mathrm{g} \mathrm{\textrm {L } ^ { - 1 }}$ $\mathrm{h}^{-1}$ for carotenoid productivity. The $\mathrm{pH}$ ranged from 5.5 to 8.7, with the highest change in the first $72 \mathrm{~h}$ of cultivation. After $96 \mathrm{~h}$ of the process, $80 \%$ of TRS had been consumed.

Malisorn and Suntornsuk (2009) compared $\beta$-carotene production by $R$. glutinis DM28 in Erlenmeyer flasks and in a stirred tank fermenter. Carotenoid production in the stirred tank fermenter 


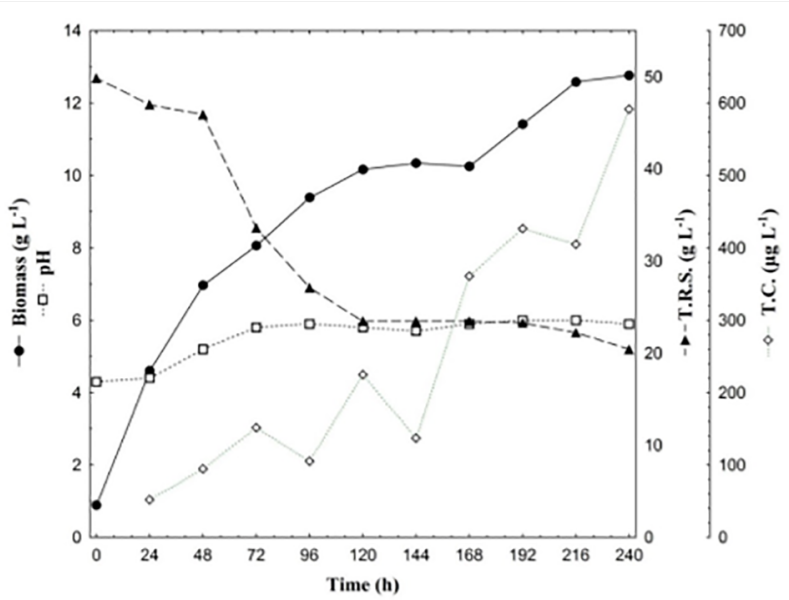

(a)

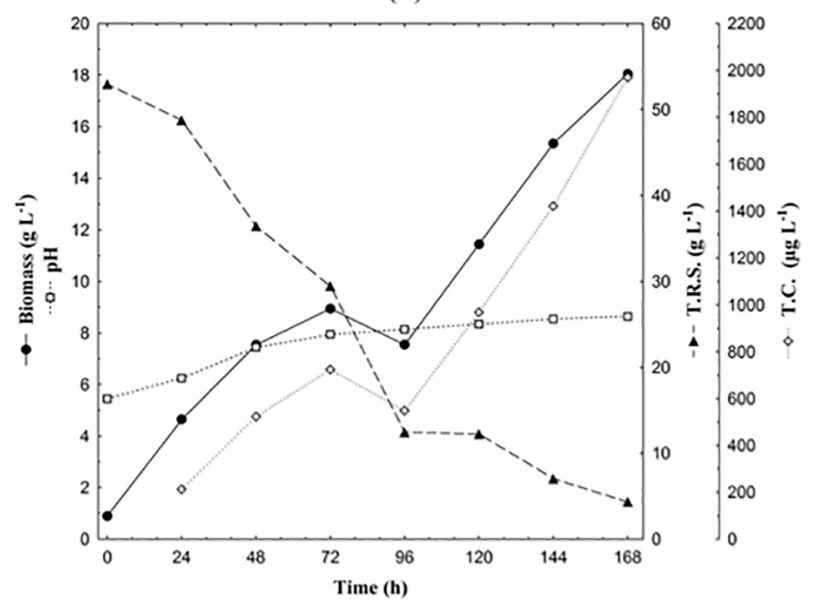

(b)

Figure 3. (a) Biomass, $\mathrm{pH}$, total carotenoids and TRS consumption in shake flasks $\left(27.5^{\circ} \mathrm{C}, 150 \mathrm{rpm}\right.$, initial $\left.\mathrm{pH}=4.0\right)$; (b) Biomass, $\mathrm{pH}$, total carotenoids and TRS consumption in the stirred tank fermenter $\left(25^{\circ} \mathrm{C}, 158\right.$ rpm, $1.2 \mathrm{vvm}$, initial $\mathrm{pH}=6.0$ ).

(186 $\left.\mu \mathrm{g} \mathrm{L}^{-1}\right)$ was approximately two times higher than in Erlenmeyer flasks $\left(87 \mu \mathrm{g} \mathrm{L}^{-1}\right)$. According to the authors, this behavior indicates that better medium homogenization and oxygen distribution caused by cultivation in the stirred tank fermenter influence the accumulation of $\beta$-carotene in yeast cells significantly, possibly due to their involvement in the stimulation of enzymes, such as phytoene desaturase, $\beta$-carotene hydroxylase and lycopene cyclase, which act on the metabolism of this carotenoid. The comparison between the maximum amount of carotenoids found in the stirred tank fermenter and that found in the validation shows that this amount was 3.3 -fold higher than the value obtained with the use of shake flasks.

Vigorous stirring is required to ensure homogeneity in the distribution of nutrients. In shake flasks, oxygen transport is a consequence of the incubator shaking, (a)

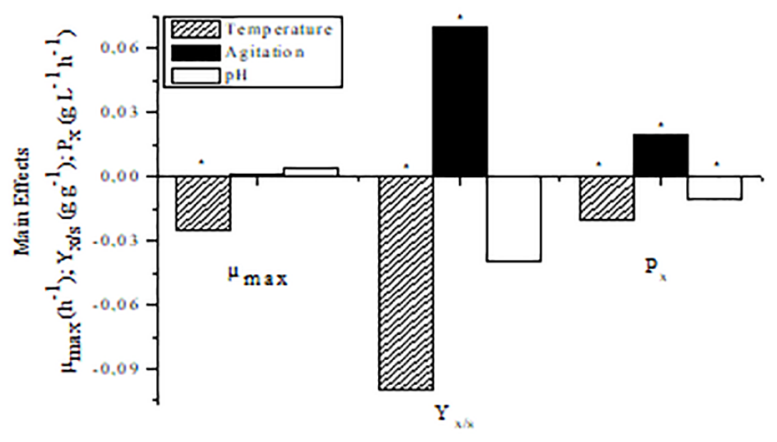

(b)

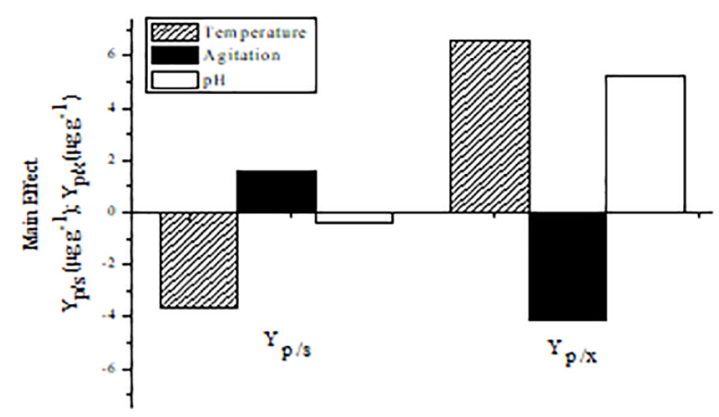

Figure 4: Effects of the variables temperature, agitation and $\mathrm{pH}$ on the responses $\mu_{\text {max }}(a), Y_{x / s}(a), P_{x}(a), Y_{p / s}(b)$ and $Y_{p / x}(b)$ by the experimental design CCRD

while in stirred tanks fermenters, the oxygen is provided by a compressed air line and distributed by a diffuser. Besides, stirring blades improve the mixing of the medium and the distribution of air bubbles, reducing their size and increasing their surface area (Garcia-Ochoa et al., 2010).

\section{CONCLUSIONS}

Conditions of temperature, agitation and $\mathrm{pH}$ were optimized in order to evaluate total carotenoid and carotenoid productivity. In the $2^{3}$ CCRD experimental design, carotenoid production showed its maximum value: $565.0 \mu \mathrm{g} \mathrm{L}^{-1}$. Production in a stirred tank fermenter, in the best conditions observed in the experimental design for carotenoid productivity, reached $1969.3 \mu \mathrm{g} \mathrm{L}^{-1}$ for carotenoids and $11.48 \mu \mathrm{g} \mathrm{L}^{-1}$ $\mathrm{h}^{-1}$ for carotenoid productivity. Carotenoid production found in cultivation in the stirred tank fermenter was 3.5-fold higher than the value obtained with shake flasks. Therefore, this study not only demonstrates the influence of the parameters temperature, agitation and $\mathrm{pH}$ on carotenoid production by the yeast $S$. pararoseus, but also shows that its capacity can be increased by modifying the parameters aeration and agitation. 


\section{ACKNOWLEDGEMENTS}

The authors would like to thank CAPES (Brazilian Agency for Improvement of Graduate Personnel) and $\mathrm{CNPq}$ (National Council of Science and Technological Development) for the financial support.

\section{NOMENCLATURE}

$\begin{array}{ll}\text { TC } & \text { total concentration of carotenoids }\left(\mu \mathrm{g} \mathrm{g}^{-1}\right) \\ \mathrm{A} & \text { absorbance } \\ \mathrm{V} & \text { volume }(\mathrm{mL}) \\ \mathrm{m}_{\text {sample }} & \text { dried cell mass }(\mathrm{g}) \\ A_{1 c m}^{1 \%} & \text { specific absorptivity } \\ \mathrm{TRS} & \text { total reducing sugars } \\ \mathrm{DNS} & \text { 3,5 dinitrosalicylic acid } \\ \mu_{\text {máx }} & \text { maximum specific growth rate }\left(\mathrm{h}^{-1}\right) \\ \mathrm{Y}_{\mathrm{p} / \mathrm{s}} & \text { TRS to product conversion factor }\left(\mu \mathrm{g} \mathrm{g}^{-1}\right) \\ \mathrm{Y}_{\mathrm{x} / \mathrm{s}} & \text { TRS to biomass conversion factor }\left(\mathrm{g} \mathrm{g}^{-1}\right) \\ \mathrm{Y}_{\mathrm{p} / \mathrm{x}} & \text { biomass to product conversion factor }\left(\mu \mathrm{g} \mathrm{g}^{-1}\right) \\ \mathrm{X}_{\mathrm{m}} & \text { maximum biomass concentration }\left(\mathrm{g} \mathrm{L}^{-1}\right) \\ \mathrm{X}_{0} & \text { initial biomass concentration }\left(\mathrm{g} \mathrm{L}^{-1}\right) \\ \mathrm{P}_{\mathrm{m}} & \text { maximum concentration of carotenoids }\left(\mu \mathrm{g} \mathrm{L}^{-1}\right) \\ \mathrm{P}_{0} & \text { initial concentration of carotenoids }\left(\mu \mathrm{g} \mathrm{L}^{-1}\right) \\ \mathrm{S}_{0} & \text { initial concentration of TRS }\left(\mathrm{g} \mathrm{L}^{-1}\right) \\ \mathrm{S} & \text { final concentration of TRS }\left(\mathrm{g} \mathrm{L}^{-1}\right) \\ \mathrm{P}_{\mathrm{c}} & \text { carotenoid productivity }\left(\mu \mathrm{g} \mathrm{L-1} \mathrm{h}^{-1}\right) \\ \mathrm{P}_{\mathrm{x}} & \text { biomass productivity }\left(\mathrm{g} \mathrm{L} \mathrm{L}^{-1} \mathrm{~h}^{-1}\right) \\ \mathrm{t}_{\mathrm{f}} & \text { time of fermentation where the maximum } \\ \mathrm{CCRD} & \text { biomass or product was obtained }(\mathrm{h}) \\ & \text { central composite rotatable design }\end{array}$

\section{REFERENCES}

Aksu, Z. and Eren, A. T., Production of carotenoids by the isolated yeast of Rhodotorula glutinis, Biochemical Engineering Journal, 35(2) 107-113 (2007).

AOAC - Association Official Analytical Chemists. Official Methods of Analysis, 17th edition. Washington, D. C., CD-ROM, (2000).

BCC Research - The global Market for Carotenoids. Access in 08/19/2016 http://www.bccresearch.com/ market-research/food-and-beverage/carotenoidsglobal-market-report-fod025e.html

Batada, A. and Jacobson, M. F., Prevalence of artificial food colors in grocery store products marketed to children, Clinical Pediatrics, 55(12) 1113-1119 (2016) DOI 10.1177/0009922816651621.
Bhosale, P., Environmental and cultural stimulants in the production of carotenoids from microorganisms, Applied Microbiology Biotechnology, 63(4) 351361 (2004).

Box, E. G. P., Hunter, W. G. and Hunter, J. S., Statistics for experiments. An introduction to designs, data analysis and model building. New York: John Wiley \& Sons (1978).

Choi, M.H. and Park, Y.H., Production of yeast biomass using waste Chinese cabbage. Biomass and Bioenergy, 25(2) 221-226 (2003).

Cipolatti, E. P., Obtenção de carotenoides microbianos com atividade antioxidante a partir de coprodutos agroindustriais. Dissertação, Universidade Federal do Rio Grande (2012).

Cipolatti, E. P., Bulsing, B. A., de Sá, C. S., Burkert, C. A. V., Furlong, E. B. and Burkert, J. D. M., Carotenoids from Phaffia rhodozyma: Antioxidant activity and stability of extracts, African Journal of Botechnology, 14(23) 1982-1988 (2015).

Cutzu, R., Clemente, A., Reis, A., Nobre, B., Mannazzu, I., Roseiro, J., and Da Silva, T. L., Assessment of $\beta$-carotene content, cell physiology and morphology of the yellow yeast Rhodotorula glutinis mutant 400A15 using flow cytometry. Journal of Industrial Microbiology and Biotechnology, 40(8) 865-875 (2013).

Dafallah, A. A., Abdellah, A. M., Absel-Rahim, E. A. and Ahmed, S. H., Physiological effects of some artificial and natural food coloring on young male albino rats, Journal of Food Technology Research, 2(2) 21-32 (2015).

Damodaram, S., Parkin, K. L. and Fennema, O. R., Fennema's Food Chemistry. 4.ed. - Boca Raton: CRC Press, 2007.

Davies, B. H. Chemical Biochemistry Plant Pigments, Academic Press: New York, (1976).

El-Banna, A. A., El-Razek, A. M. A. and El-Mahdy, A. R., Some factors affecting the production of carotenoids by Rhodotorula glutinis var. glutinis, Food and Nutrition Sciences, 3(1) 64-71 (2012).

Fonseca, R. A. S., da Silva Rafael, R., Kalil, S. J.; Burkert, C. A. V. and Medeiros Burkert, J. F., Different cell disruption methods for astaxanthin recovery by Phaffia rhodozyma, African Journal of Biotechnology, 10(7) 1165-1171 (2011).

Fossi, B. T., Anyangwe, I.; Tavea, F.; Lucas, K. E. and Nkuo, T. A., Lactic acid bacteria from traditionally processed corn beer and palm wine against selected food-borne pathogens isolated in south west region 
of Cameroon, African Journal of Microbiology Research, 10(30) 1140-1147 (2016).

Frengova, G. I. and Beshkova, D. M., Carotenoids from Rhodotorula and Phaffia: yeasts of biotechnological importance, Journal of Industrial Microbiology and Biotechnology, 36(2), p. 163 (2009) https://doi.org/10.1007/s10295-008-04929.

Garcia-Ochoa, F., Gomez, E., Santos, V. E. and Marchuk, J. C., Oxygen uptake rate in microbial processes: an overview, Biochemical Engineering Journal, 49(3) 289-307 (2010).

Gong, Z., Zhou, W., Shen, H., Zhao, Z., Yang, Z., Yan, J. and Zhao, M., Co-utilization of corn stover hydrolysates and biodiesel-derived glycerol by Cryptococcus curvatus for lipid production, Bioresource Technology, 219 552-558 (2016).

Hiss, H. Cinética de processos fermentativos. In: Schimidell, W.; Lima, U.A.; Aquarone, E.; Borzani, W. Biotecnologia Industrial: Engenharia Bioquímica. Ed. Edgar Blücher Ltda, São Paulo (2001).

Ni, H., Chen, Q. H., Ruan, H., Yang, Y. F., Li, L. J., Wu, G. B., Hu, Y. and He, G. Q., Studies on optimization of nitrogen sources for astaxanthin production by Phaffia rhodozyma, Journal of Zhejiang University SCIENCE B, 8(5) 365-370 (2007).

Instituto Brasileiro de Geografia e Estatística (IBGE). Indicadores IBGE: estatística da produção agrícola. (2016). ftp://ftp.ibge.gov.br/ Producao_Agricola/Fasciculo_Indicadores_IBGE/ estProdAgr_201611_20161214_100000.pdf

Ju, L. K. and Chase, G. G., Improved scale-up strategies of bioreactors, Bioprocess Engineering, 8(1-2), 49-53 (1992).

Kavino, M., Harish, S., Kumar, N., Saravanakumar, D., Damodaran, T., Soorianathsundaram, K. and Samiyappan, R., Rhizosphere and endophytic bacteria for induction of $\mathrm{s}$ systemic resistance of banana plantlets against bunchy top virus, Soil Biology and Biochemistry, 39(5) 1087-1098 (2007).

Liggett, W. R. and Koffler, H., Corn steep liquor in microbiology, Bacteriology Reviews, 12(4) $297-$ 311 (1948).

Liu, Y., Wu, J. and Ho, K., Characterization of oxygen transfer conditions and their effects on Phaffia rhodozyma growth and carotenoid production in shake-flask cultures. Bichemical Engineering Journal, 27(3) 331-335 (2006).
Machado, W. R. C. and Medeiros Burkert, J. F., Optimization of agroindustrial medium for the production of carotenoids by wild yeast Sporidiobolus pararoseus. African Journal of Microbiology Research, 9(4) 209-219 (2015).

Maldonade, I. R., Carvalho, P. G. B. and Ferreira, N. A., Comunicado técnico 85: Protocolo para determinação de açúcares totais em hotaliças pelo método de DNS. Brasília: Embrapa Hortaliça (2013).

Malisorn, C. and Suntornsuk, W., Improved $\beta$-carotene production of Rhodotorula glutinis in fermented radish brine by continuous cultivation. Biochemical Engineering Journal, 43(1) 27-32 (2009).

Mantzouridou, F., Roukas, T. and achatz, B., Effect of oxygen transfer rate on $\beta$-carotene production from synthetic medium by Blakeslea trispora in shake flask culture. Enzime and Microbial Technology, 37(7) 687-694 (2005).

Mantzouridou, F., Roukas, T. and Kotzekidou, P., Effect of the aeration rate and agitation speed on carotene production and morphology of Blakeslea trispora in a stirred tank reactor: mathematical modeling. Biochemical Engineering Journal, 10(2) 123-135 (2002).

Michelon, M., de Borba, T. M., da Silva Rafael, R., Burkert, C. A. V. and de Medeiros-Burkert, J. F., Extraction of carotenoids from Phaffia rhodozyma: A comparison between different techniques of cell disruption. Food Science and Biotechnology, 21(1) 1-8 (2012).

Miller, G. L. Use of dinitrosalicylic acid reagent for determination of reducing sugar. Analytical Chemistry, 31(3) 426-428 (1959).

Otero, D. M. Bioprospecção de leveduras silvestres produtoras de carotenoides. Dissertação Universidade Federal do Rio Grande (2011).

Otero, D. M., Cadaval, C. L., Teixeira, L. M., Rosa, C. A., Sanzo, A. V. L. and Kalil, S. J., Screening of yeasts capable of producing cellulase-free xylanase. African Journal of Biotechnology, 14(23) 1961-1969 (2015).

Pleszczynska, M., Wianter, A., Siwulski, M., Lemieszek, M. M., Kunaszewska, J., Kaczor, J., Reski, W., Janusz, G. and Szczodrak, J., Cultivation and utility of Piptoporus betulinus fruiting bodies as a source of anticancer agents. World Journal of Microbiology and Biotechnology, 32(9), 151 (2016).

Riaño, B., Blanco, S., Becares, E. and GarcíaGonzález, M. C., Bioremediation and biomass 
harvesting of anaerobic digested cheese whey in microalgal-based systems for lipid production. Ecological Engineering, 97 40-45 (2016).

Rios, D.A.S., Borba, T.M., Kalil, S.J. and Burkert, J. F. M., Rice parboiling wastewater in the maximization of carotenoids bioproduction by Phaffia rhodozyma. Ciência e Agrotecnologia, 39(4) 401-410 (2015).

Rodrigues, M. I. and Iemma, A. F., Experimental design and processes optimization. Casa do Espírito Amigo Fraternidade Fé e Amor. 2nd. Campinas, São Paulo (2012).

Saenge, C., Cheirsilp, B., Suksaroge, T. T. and Bourtoom, T., Potential use of oleaginous red yeast Rhodotorula glutinis for the bioconversion of crude glycerol from biodiesel plant to lipids and carotenoids. Process Biochemistry, 46(1) 210-218 (2011).
Tinoi, J., Rakariyatham, N. and Deming, R. L., Simplex optimization of carotenoid production by Rhodotorula glutinis using hydrolyzed mung bean waste flour substrate, Process Biochemistry, 40(7) 2551-2557 (2005).

Valduga, E., Valério, A., Treichel, H., Di Luccio, M., Jacques, R.A., and Junior, A.F., Pré-tratamentos de melaço de cana-de-açúcar e água de maceração de milho para a bioprodução de carotenóides. Química Nova, 30(8) 1860-1866 (2007).

Valduga, E, Valerio, A., Treichel, H., Di Luccio, M. and Furigo Junior, A., Study of the bio-production of carotenoids by Sporidiobolus salmonicolor (CBS 2636) using pre-treated agro-industrial substrates. Journal of Chemical Technology and Biotechnology, 83(9) 1267-1274 (2008). 
